\title{
Effect of captopril on kidney function in insulin-dependent diabetic patients with nephropathy
}

\author{
EVA HOMMEL, HANS-HENRIK PARVING, \\ META DAMKJæR NIELSEN， JØRN GIESE
}

\begin{abstract}
The influence of angiotensin II on kidney function in diabetic nephropathy was assessed by studying the effect of 12 weeks' monotherapy with captopril (25-50 $\mathrm{mg}$ twice a day) in 16 hypertensive insulin dependent diabetic patients with persistent albuminuria. In an initial one week randomised single blind trial of captopril versus placebo, captopril (for nine patients) reduced arterial blood pressure from $148 / 94($ SD11/6) to $135 / 88(8 / 7)$ $\mathrm{mm} \mathrm{Hg}(\mathrm{p}<0.05)$ and albuminuria from 1549 (range 352-2238) to $1170(297-2198) \mu \mathrm{g} / \mathrm{min}(\mathbf{p}<0.05)$, while glomerular filtration rate remained stable. No significant changes occurred in seven patients treated with placebo. During the 12 weeks of captopril treatment arterial blood pressure in all patients fell from 147/94 $(11 / 6)$ to $135 / 86(13 / 7) \mathrm{mm} \mathrm{Hg}(\mathrm{p}<0.01)$, albuminuria fell from 1589 (range 168-2588) to $1075(35-2647) \mu \mathrm{g} / \mathrm{min}(\mathbf{p}<0.01)$, and glomerular filtration rate fell from 99 (SD19) to $93(25) \mathrm{ml} / \mathrm{min} / 1 \cdot 73$ $\mathbf{m}^{2}(\mathbf{p}<\mathbf{0} \cdot 01)$. The renin-angiotensin system showed suppressed plasma concentrations of angiotensin II and increased concentrations of angiotensin $I$ and renin.

The study showed that glomerular filtration rate is not dependent on angiotensin II, that captopril reduces albuminuria, probably by lowering glomerular hypertension, and that captopril represents a valuable new drug for treating hypertension in diabetics dependent on insulin with nephropathy.
\end{abstract}

Hvidöre Hospital, DK 2930 Klampenborg, Denmark

EVA HOMMEL, MD, registrar

HANS-HENRIK PARVING, MD, chief physician

ELISABETH MATTHIESEN, MD, registrar

BERIT EDSBERG, $M D$, senior registrar

Department of Clinical Physiology, Glostrup Hospital, Copenhagen, Denmark META DAMKJÆR NIELSEN, MSC, biochemist in chief JØRN GIESE, MD, chief physician

Correspondence to: Dr Parving.
ELISABETH MATHIESEN, BERIT EDSBERG, Introduction

Several recent studies have shown that the renin-angiotensin system plays a crucial part in regulating glomerular filtration rate when renal perfusion pressure and plasma flow are reduced owing to renal artery stenosis or widespread intrarenal arterial lesions. ${ }^{1.5}$ Diabetic glomerulosclerosis is characterised by widespread arteriolar hyalinosis, which may lead to reduced renal plasma flow. ${ }^{6}$ These findings suggest that angiotensin II may be important for regulating glomerular filtration rate in diabetic nephropathy. Furthermore, angiotensin II induces proteinuria, mainly by increasing glomerular capillary hydraulic pressure. ${ }^{7}$ Recent studies have suggested a link between glomerular hypertension, albuminuria, and the development and progression of diabetic glomerulopathy. ${ }^{89}$

To evaluate the influence of angiotensin II on kidney function in diabetic nephropathy we investigated the effect of angiotensin converting enzyme inhibition with captopril on glomerular filtration rate and albuminuria in hypertensive diabetics dependent on insulin and with persistent albuminuria.

\section{Patients and methods}

PATIENTS

We examined the records of all insulin dependent diabetics with proteinuria (positive Albustix) visiting the outpatient clinic at Hvidöre Hospital during 1984. All hypertensive patients aged under 50 with persistent albuminuria ( $>300 \mathrm{mg} /$ day), a serum creatinine concentration less than $120 \mu \mathrm{mol} / 1(1.36 \mathrm{mg} / 100 \mathrm{ml})$, and no oedema who had developed diabetes before the age of 31 years but were receiving no antihypertensive treatment (including diuretics) and were not blind were invited to join the study. Seventeen patients fulfilled these criteria and all gave fully informed consent. The patients were randomly allocated to treatment $(n=9)$ or placebo $(n=8)$. At the start of the study we had to omit one patient in the placebo group because treatment with thiazide had been started owing to oedema. The remaining 16 patients (table I) were investigated. The experimental design was approved by the local ethical committee.

All patients were insulin dependent from the time of diagnosis and all received two daily injections of highly purified porcine insulin (mean dose $0.61 \mathrm{U} / \mathrm{kg} / \mathrm{day}$ ). None of the patients were taking any other drugs. All patients kept their normal diabetic diet without sodium restriction throughout the study. Nephropathy was diagnosed clinically according to previously described criteria. ${ }^{10}$ 
TABLE I-Clinical data on insulin dependent diabetic patients with nephropathy

\begin{tabular}{|c|c|c|c|c|c|c|c|}
\hline Case No & Sex & $\begin{array}{c}\text { Age } \\
\text { (years) }\end{array}$ & $\begin{array}{c}\text { Duration of } \\
\text { diabetes } \\
\text { (years) }\end{array}$ & Retinopathy & $\begin{array}{l}\text { Insulin } \\
\text { dose } \\
\mathrm{U} / \mathrm{kg} / \text { day })\end{array}$ & $\begin{array}{l}\text { Arterial* } \\
\text { blood } \\
\text { pressure } \\
(\mathrm{mm} \mathrm{Hg})\end{array}$ & $\begin{array}{l}\text { Captopril† } \\
\text { treatment } \\
\quad(\mathrm{mg})\end{array}$ \\
\hline 1 & $M$ & 43 & 20 & Simplex & 0.49 & $157 / 92$ & 100 \\
\hline 2 & M & 34 & 18 & Proliferative & 0.55 & $158 / 100$ & 100 \\
\hline 3 & M & 46 & 20 & Proliferative & 0.63 & $161 / 81$ & 75 \\
\hline 4 & M & 30 & 20 & Proliferative & $0 \cdot 41$ & $152 / 102$ & 100 \\
\hline 5 & $M$ & 24 & 15 & Simplex & $0 \cdot 80$ & $147 / 97$ & 100 \\
\hline 6 & $M$ & 29 & 15 & Proliferative & 0.49 & $159 / 98$ & 100 \\
\hline 7 & M & 31 & 27 & Proliferative & 0.80 & $140 / 100$ & 100 \\
\hline 8 & M & 19 & 13 & Simplex & 0.96 & $150 / 99$ & 100 \\
\hline 9 & M & 19 & 15 & Proliferative & 0.84 & $183 / 95$ & 100 \\
\hline 10 & M & 34 & 28 & Proliferative & 0.62 & $155 / 97$ & 50 \\
\hline 11 & $M$ & 26 & 19 & Proliferative & 0.75 & $148 / 103$ & 100 \\
\hline 12 & $\mathrm{~F}$ & 25 & 18 & Simplex & 0.42 & $136 / 99$ & 50 \\
\hline 13 & M & 43 & 20 & Proliferative & 0.67 & $158 / 108$ & 100 \\
\hline 14 & $\mathrm{~F}$ & 23 & 22 & Simplex & 0.53 & $150 / 112$ & 50 \\
\hline 15 & $M$ & 30 & 17 & Simplex & 0.50 & $153 / 107$ & 75 \\
\hline 16 & $M$ & 46 & 42 & Simplex & 0.56 & $162 / 97$ & 50 \\
\hline $\operatorname{Mean}(\mathrm{SD}$ & & $31(9)$ & $20(7)$ & & $0.63(0.20) 1$ & $154 / 99(11 / 7)$ & $84(22)$ \\
\hline
\end{tabular}

${ }^{\star}$ Mean of last three measurements performed in outpatient clinic before start of study. †Mean dose during 12 weeks' treatment.

\section{METHODS}

All patients were initially studied between January and April 1985; all investigations were carried out on one day, between 0830 and 1500 . Patients had their normal breakfast and morning insulin before the investigations, during which the patients were resting supine. The patients stood up only to pass urine. The patients drank $200 \mathrm{ml}$ of tap water per hour during the study.

The study was performed before and after one week's treatment with captopril (cases 1-9) or placebo (cases 10-16) in a single blind design. All patients were reinvestigated after a subsequent 12 weeks of treatment with captopril alone. Each patient underwent a single dose titration starting with $6.25 \mathrm{mg}$ captopril or placebo (1300-1500). Depending on the acute blood pressure response and the glomerular filtration rate, the dose was increased to $12 \cdot 5-25 \mathrm{mg}$ twice daily. Three days later blood pressure was taken and the dose adjusted to $25-50 \mathrm{mg}$ twice daily. The adjusted dose $(84 \mathrm{mg})$ was kept constant throughout the 12 weeks' trial. The patients were seen in the outpatient clinic four weeks after start of captopril treatment.

Plasma volume was determined (at 0845) from the intravenously injected amount of human serum albumin labelled with iodine-125 (Code MIAK,
Institute of Atomic Energy, Kjeller, Norway) measured by weighing and from the plasma radioactivity sampled after a mixing period of 15 minutes.

Glomerular filtration rate and extracellular fluid volume were measured after a single intravenous injection of $3.7 \mathrm{MBq}$ chromale- $5^{\prime}$ edetic acid (0900) by studying the plasma disappearance for four hours. ${ }^{11} 12$ Blood samples for tracer determinations were drawn before the injection and at $5,7,10,15,30$, $45,60,90,120,150,180,200,220$, and 240 minutes after the ${ }^{51} \mathrm{Cr}$ edetic acid injection. The mean coefficient of variation between patients for glomerular filtration rate was $2 \cdot 8 \%$.

Urinary albumin excretion was measured during the four hour clearance period by radioimmunoassay. ${ }^{13}$ This assay has a sensitivity of $0.5 \mathrm{mg} / \mathrm{l}$ and an interassay coefficient of variation of $9 \%$. Blood pressure was measured with a Hawksley random zero device (cuff $25 \times 12 \mathrm{~cm}$ ) on the right arm. Blood pressure and heart rate were measured every half hour during each study. Diastolic blood pressure was recorded at the disappearance of the Korotkoff sounds (phase V)

Plasma concentrations of renin substrate, ${ }^{14}$ active renin, ${ }^{15}$ angiotensin $I,{ }^{16}$ angiotensin II,${ }^{17}$ aldosterone, ${ }^{18}$ and albumin ${ }^{19}$ were measured in peripheral blood between 1000 and 1100 . Recumbent values after one hour's rest are shown. Blood glucose was measured hourly during the four hour clearance period by the reflectance meter Reflomat (Boehringer-Mannheim, Ingelheim, West Germany). Plasma electrolytes, leucocytes, and cholesterol were measured during each investigation using conventional laboratory techniques. Stable haemoglobin $\mathrm{A}_{\mathrm{lc}}$ was measured before and after 12 weeks of captopril treatment (normal range $4 \cdot 1-6 \cdot 1 \%$ of total haemoglobin). ${ }^{20}$ Retinopathy was assessed by direct ophthalmoscopy after pupillary dilatation.

\section{STATISTICAL ANALYSIS}

Wilcoxon's non-parametric test for unpaired and paired comparison was used for statistical analysis. Mean values are given with the standard deviation; as urinary albumin excretion is not normally distributed median and range are used.

\section{Results}

Captopril treatment (25-50 mg twice daily) for one week reduced arterial blood pressure from $148 / 94(11 / 6)$ to $135 / 88(8 / 7) \mathrm{mm} \mathrm{Hg}(\mathbf{p}<0.05)$, albuminuria diminished from $1549(352-2238)$ to $1170(297-2198) \mu \mathrm{g} / \mathrm{min}$ $(\mathrm{p}<0.05)$, and glomerular filtration rate remained stable $(97(19)$ before and $96(20) \mathrm{ml} / \mathrm{min} / 1 \cdot 73 \mathrm{~m}^{2}$ during treatment) (table II). No significant changes occurred in arterial blood pressure, glomerular filtration rate, and

TABLE II-Arterial blood pressure, glomerular filtration rate, and albuminuria before and after one and 12 weeks' monotherapy with captopril in 16 insulin dependent diabetic patients with nephropathy

\begin{tabular}{|c|c|c|c|c|c|c|c|c|c|}
\hline \multirow[b]{2}{*}{ Case No } & \multicolumn{3}{|c|}{$\begin{array}{l}\text { Arterial blood pressure } \\
(\mathrm{mm} \mathrm{Hg})(\mathrm{SD})\end{array}$} & \multicolumn{3}{|c|}{$\begin{array}{l}\text { Glomerular filtration rate } \\
\left(\mathrm{ml} / \mathrm{min} / 1.73 \mathrm{~m}^{2}\right)\end{array}$} & \multicolumn{3}{|c|}{$\underset{(\mu \mathrm{g} / \mathrm{min})}{\text { Albuminuria }}$} \\
\hline & Baseline & $\begin{array}{l}\text { After lst week } \\
\text { captopril } v \text { placebo }\end{array}$ & $\begin{array}{l}\text { After } 12 \text { weeks' } \\
\text { captopril }\end{array}$ & Baseline & $\begin{array}{l}\text { After lst week } \\
\text { captopril } v \text { placebo }\end{array}$ & $\begin{array}{l}\text { After } 12 \text { weeks' } \\
\text { captopril }\end{array}$ & Baseline & $\begin{array}{l}\text { After lst week } \\
\text { captopril } v \text { placebo }\end{array}$ & $\begin{array}{l}\text { After } 12 \text { weeks' } \\
\text { captopril }\end{array}$ \\
\hline \multicolumn{10}{|c|}{ Patients who received captopril in first week } \\
\hline 1 & $147 / 88(8 / 9)$ & $137 / 88(4 / 4)$ & $149 / 91(7 / 6)$ & 85 & 88 & 80 & 1101 & 844 & 1141 \\
\hline 2 & $129 / 86(8 / 5)$ & $120 / 84(5 / 4)$ & $120 / 76(10 / 8)$ & 70 & 71 & 59 & 1549 & 1170 & 694 \\
\hline 3 & $158 / 92(8 / 4)$ & $141 / 83(3 / 3)$ & $153 / 90(4 / 7)$ & 82 & 77 & 75 & 2238 & 2198 & 1328 \\
\hline 4 & $164 / 94(7 / 7)$ & $137 / 86(4 / 3)$ & $146 / 91(8 / 4)$ & 93 & 93 & 88 & 1677 & 1165 & 1121 \\
\hline 5 & $134 / 96(7 / 5)$ & $140 / 98(3 / 9)$ & $126 / 86(3 / 4)$ & 104 & 101 & 99 & 745 & 302 & 315 \\
\hline 6 & $155 / 94(6 / 5)$ & $144 / 91(5 / 6)$ & $139 / 93(4 / 6)$ & 115 & 122 & 119 & 352 & 297 & 195 \\
\hline 7 & $151 / 104(5 / 4)$ & $134 / 100(5 / 3)$ & $132 / 91(6 / 4)$ & 104 & 92 & 99 & 1864 & 1900 & 1663 \\
\hline 8 & $141 / 92(4 / 4)$ & $123 / 87(7 / 5)$ & $129 / 84(5 / 3)$ & 134 & 133 & 151 & 1489 & 1396 & 1055 \\
\hline 9 & $153 / 100(5 / 3)$ & $142 / 79(6 / 10)$ & $151 / 86(5 / 3)$ & 89 & 86 & 85 & 2021 & 1914 & 2647 \\
\hline $\begin{array}{l}\text { Mean }(S D) \\
(n=9)\end{array}$ & $148 / 94(11 / 6)$ & $\begin{array}{c}135 / 88 \quad(8 / 7) \\
p<0.05\end{array}$ & & $97(19)$ & $\begin{array}{l}96(20) \\
\text { NS }\end{array}$ & & $1549^{\star}($ range $352-2238)$ & $\begin{array}{l}1170 \text { (range 297-2198) } \\
\mathrm{p}<0.05\end{array}$ & \\
\hline \multicolumn{10}{|c|}{ Patients who received placebo in first week } \\
\hline 10 & $133 / 90(7 / 2)$ & $139 / 93(4 / 2)$ & $126 / 85(3 / 3)$ & 80 & 85 & 79 & 1628 & 1934 & 1092 \\
\hline 11 & $129 / 93(4 / 5)$ & $134 / 93(4 / 4)$ & $122 / 79(1 / 5)$ & 124 & 124 & 108 & 275 & 293 & 167 \\
\hline 12 & $152 / 98(3 / 9)$ & $136 / 96(5 / 1)$ & $129 / 82(7 / 4)$ & 134 & 136 & 127 & 626 & 604 & 720 \\
\hline 13 & $161 / 102(5 / 3)$ & $151 / 95(4 / 4)$ & $147 / 96(8 / 7)$ & 91 & 91 & 81 & 2097 & 2288 & 1156 \\
\hline 14 & $154 / 100(11 / 2)$ & $147 / 94(9 / 6)$ & $109 / 72(6 / 6)$ & 81 & 74 & 52 & 2588 & 2178 & 483 \\
\hline 15 & $141 / 88(4 / 3)$ & $137 / 89(3 / 4)$ & $138 / 87(4 / 1)$ & 96 & 94 & 94 & 168 & 96 & $34 \cdot 7$ \\
\hline 16 & $156 / 85(7 / 2)$ & $149 / 88(6 / 2)$ & $138 / 83(4 / 4)$ & 94 & 84 & 93 & 2946 & 3665 & 2351 \\
\hline $\begin{array}{l}\text { Mean }(S D) \\
(n=7)\end{array}$ & $147 / 94(12 / 6)$ & $\begin{array}{c}142 / 92(12 / 3) \\
\mathrm{p}<0.01\end{array}$ & & $100(21)$ & $\begin{aligned} & 98(23) \\
\mathrm{p} & <0.01\end{aligned}$ & & $1628^{\star}$ (range $\left.168-2588\right)$ & $\begin{array}{l}\left.1934^{\star} \text { (range } 96-3665\right) \\
\mathrm{p}<0.01\end{array}$ & \\
\hline $\begin{array}{l}\operatorname{Mean}(S D) \\
(n=16)\end{array}$ & $147 / 94(11 / 6)$ & $\mathrm{p}<0.01$ & $135 / 86(13 / 7)$ & $99(19)$ & $\mathrm{p}<0.01$ & $93(25)$ & $1589^{\star}$ (range $\left.168-2588\right)$ & $\begin{array}{l}1075^{\star} \text { (range } 34 \cdot 7-2647 \text { ) } \\
p<0.01\end{array}$ & \\
\hline
\end{tabular}

^Median value and range. 
albuminuria in the seven patients treated with placebo (table II). Plasma concentrations of renin substrate, active renin, angiotensin I and II, and plasma aldosterone concentration were all within the normal range before captopril treatment (table III). The renin-angiotensin system showed suppressed plasma concentration of angiotensin II, increased concentrations of angiotensin $I$ and renin, and a clearly raised ratio between angiotensin I and II ( 3.3 before, $12 \cdot 1$ after captopril) $(p<0.01)$, indicating inhibition of converting enzyme activity. Blood glucose concentration was $11 \cdot 2$ (3) $\mathrm{mmol} / \mathrm{l}(201 \cdot 8(54) \mathrm{mg} / 100 \mathrm{ml})$ before and $11 \cdot 0(4) \mathrm{mmol} / \mathrm{l}(198 \cdot 2(72 \cdot 1)$ $\mathrm{mg} / 100 \mathrm{ml}$ ) after captopril treatment for one week. Table IV compares the changes in measured variables during one week's treatment with captopril or placebo.
$8.9(2) \%$ before and $9 \cdot 2(1) \%$ during captopril treatment). The insulin dose remained constant during the study, at $0.63(0.2) \mathrm{U} / \mathrm{kg} /$ day before and 0.62 $(0 \cdot 2) \mathrm{U} / \mathrm{kg} /$ day at 12 weeks. Serum concentrations of potassium, sodium, and cholesterol showed no significant changes during captopril treatment: $3.9(0.3)$ to $3.9(0.4) \mathrm{mmol}(\mathrm{mEq}) / 1,136(2)$ to $137(2) \mathrm{mmol}(\mathrm{mEq}) / \mathrm{l}$, and $6 \cdot 1(1 \cdot 0) \mathrm{mmol} / \mathrm{l}(235 \cdot 5(38 \cdot 6) \mathrm{mg} / 100 \mathrm{ml})$ to $6 \cdot 3(0 \cdot 6) \mathrm{mmol} / \mathrm{l}(243 \cdot 2(23 \cdot 2)$ $\mathrm{mg} / 100 \mathrm{ml})$, respectively.

None of the 16 patients experienced rash, taste disturbance, headache, fatigue, depression, orthostatic symptoms, or sexual dysfunction. Neutropenia was not observed. All but two patients had reduced albuminuria. All 16 patients are still receiving captopril, either alone or in combination with a diuretic drug.

TABLE III-Mean (SD) plasma concentrations of renin substrate, active renin, angiotensin I and II, and aldosterone and urinary sodium excretion before and after one and 12 weeks' monotherapy with captopril in 16 insulin dependent diabetic patients with nephropathy

\begin{tabular}{|c|c|c|c|c|c|c|c|}
\hline & $\begin{array}{c}\text { Renin } \\
\text { substrate } \\
(\mu \mathrm{mol} \\
\text { angiotensin } \mathrm{I} / \mathrm{l})\end{array}$ & $\begin{array}{l}\text { Active } \\
\text { renin } \\
(\mathrm{mU} / \mathrm{l})\end{array}$ & $\underset{(\mathrm{pmol} / \mathrm{l})}{\text { Angiotensin I }}$ & $\begin{array}{l}\text { Angiotensin II } \\
(\mathrm{pmol} / \mathrm{l})\end{array}$ & $\begin{array}{l}\text { Angiotensin } \mathrm{V} / \\
\text { angiotensin II }\end{array}$ & $\begin{array}{l}\text { Aldosterone } \\
(\mathrm{pmol} / \mathrm{l})\end{array}$ & $\begin{array}{c}\text { Urinary } \\
\text { sodium } \\
\text { excretion } \\
(\mathrm{mmol} / \mathrm{min})\end{array}$ \\
\hline \multicolumn{8}{|l|}{ Cases 1 to 9} \\
\hline Before & $1 \cdot 2(0 \cdot 2)$ & $52(23)$ & $21(8)$ & $7 \cdot 5(3 \cdot 5)$ & $3-3(1 \cdot 7)$ & $68(37)$ & $0 \cdot 19(0 \cdot 1)$ \\
\hline 1 week (captopril) & $1 \cdot 1(0 \cdot 2)$ & $103\left(70^{\star}\right)$ & $70(65 t)$ & 5.0 (2.9+) & $12 \cdot 1(5 \cdot 7 \dagger)$ & $59(26)$ & $0 \cdot 19(0 \cdot 1)$ \\
\hline \multicolumn{8}{|l|}{ Cases 10 to 16} \\
\hline Before & $1 \cdot 2(0 \cdot 3)$ & $29(12)$ & $24(9)$ & $4 \cdot 8(4 \cdot 9)$ & $6.9(3.4)$ & $72(42)$ & $0 \cdot 20(0 \cdot 1)$ \\
\hline 1 week (placebo) & $1 \cdot 2(0 \cdot 2)$ & $29(12)$ & $28(12)$ & $8 \cdot 1(2 \cdot 7)$ & $3.5(0.7)$ & $76(68)$ & $0 \cdot 18(0 \cdot 1)$ \\
\hline \multicolumn{8}{|l|}{ Cases 1 to 16} \\
\hline Before & $1 \cdot 2(0 \cdot 2)$ & $42(22)$ & $22(8)$ & $6 \cdot 4(4 \cdot 2)$ & $4 \cdot 8(3 \cdot 0)$ & $70(38)$ & $0 \cdot 19(0 \cdot 1)$ \\
\hline 12 weeks (captopril) & $1 \cdot 2(0 \cdot 2)$ & $92(52 t)$ & $82(70 \dagger)$ & $7 \cdot 1(3 \cdot 7)$ & $12 \cdot 6(8 \cdot 3 t)$ & $64(45)$ & $0 \cdot 16(0 \cdot 1)$ \\
\hline Normal range & $0 \cdot 25-2 \cdot 1$ & $6-60$ & $6-34$ & $3-30$ & $1-3$ & $60-440$ & \\
\hline
\end{tabular}

TABLE IV-Mean (SD) changes in arterial blood pressure, glomerular filtration rate, albuminuria, plasma concentrations of renin substrate, active renin, angiotensin I and $I I$, and aldosterone during one week's treatment with captopril or placebo in 16 insulin dependent diabetic patients with nephropathy

\begin{tabular}{|c|c|c|c|}
\hline & $\begin{array}{l}\text { Cases } 1 \text { to } 9 \\
\text { (captopril) }\end{array}$ & $\begin{array}{l}\text { Cases } 10 \text { to } 16 \\
\text { (placebo) }\end{array}$ & $\mathrm{p}$ Value \\
\hline $\begin{array}{l}\text { Systolic blood pressure }(\mathrm{mm} \mathrm{Hg}) \\
\text { Diastolic blood pressure }(\mathrm{mm} \mathrm{Hg}) \\
\text { Glomerular filtration rate } \\
\left.\text { (ml/min } / 1 \cdot 73 \mathrm{~m}^{2}\right) \\
\text { Albuminuria }(\mu \mathrm{g} / \mathrm{min}) \\
\text { Renin substrate }(\mu \mathrm{mol} \text { angiotensin } \mathrm{I} / \mathrm{l}) \\
\text { Active renin }(\mathrm{mU} / \mathrm{l}) \\
\text { Angiotensin } \mathrm{I}(\mathrm{pmol} / \mathrm{l}) \\
\text { Angiotensin } \mathrm{II}(\mathrm{pmol} / \mathrm{l}) \\
\text { Angiotensin } \mathrm{I} / \text { angiotensin II } \\
\text { Aldosterone }(\mathrm{pmol} / \mathrm{l})\end{array}$ & $\begin{array}{l}-12 \cdot 7(8 \cdot 9) \\
-5 \cdot 6(6 \cdot 7) \\
\\
-1 \cdot 4(5) \\
-205(198) \\
0 \cdot 12(0 \cdot 2) \\
51(77) \\
50(63) \\
-2 \cdot 5(4 \cdot 5) \\
9 \cdot 9(7) \\
-9 \cdot 3(44)\end{array}$ & $\begin{aligned} &-4 \cdot 7(7 \cdot 9) \\
&-1 \cdot 1(4 \cdot 1) \\
&-1 \cdot 7(5) \\
& 104(352) \\
& 0(0) \\
&-0 \cdot 1(16) \\
& 5(15) \\
& 3(4 \cdot 2) \\
& 3 \cdot 2(3 \cdot 1) \\
&-0 \cdot 3(87)\end{aligned}$ & $\begin{array}{l}<0.05 \\
\text { NS } \\
\text { NS } \\
<0.05 \\
\text { NS } \\
<0.01 \\
<0.01 \\
<0.05 \\
<0.01 \\
\text { NS }\end{array}$ \\
\hline
\end{tabular}

Treatment of the whole group of patients with captopril (25-50 mg twice daily) for 12 weeks induced the following changes in the 16 patients: mean arterial blood pressure decreased from $147 / 94$ (11/6) to $135 / 86$ (13/7) $\mathrm{mm} \mathrm{Hg}$ $(\mathrm{p}<0.01$ ), mean albuminuria from 1589 (range 168-2588) to 1075 (range $35-2647) \mu \mathrm{g} / \mathrm{min}(\mathrm{p}<0.01)$, and mean glomerular filtration rate from $99(20)$ to $93(25) \mathrm{ml} / \mathrm{min} / 1.73 \mathrm{~m}^{2}(\mathrm{p}<0.01)$ (table II). The reduction in relative glomerular filtration rate was more than $10 \%$ in four patients (cases $2,11,13$, and 14). Both plasma and extracellular fluid volume diminished during treatment with captopril from 3081 (433) to 2985 (554) $\mathrm{ml}$ (NS) and 16196 (2588) to $15136(2885) \mathrm{ml}(\mathrm{p}<0.01)$, respectively. Plasma albumin concentration remained stable, $477(60)$ before and $483(50) \mu \mathrm{mol} / \mathrm{l}$ during treatment. A 23 year old woman (case 14) had the largest drop in mean arterial blood pressure $(24 \mathrm{~mm} \mathrm{Hg})$ and glomerular filtration rate (29 $\mathrm{ml} / \mathrm{min} / 1 \cdot 73 \mathrm{~m}^{2}$ ) during captopril treatment. Her renin-angiotensin system was normal, and radioisotope renography showed normal bilateral kidney function, excluding the possibility of renal artery stenosis.

Table III shows inhibition of the angiotensin converting enzyme activity, as indicated by the clearly raised ratio between angiotensin I and II. Urinary sodium excretion measured during the four hour clearance showed a slight, insignificant reduction during captopril treatment. Blood glucose concentration, measured hourly during the four hour clearance period, was lower after 12 weeks of captopril treatment, mean 8.9 (4) $\mathrm{mmol} / 1$, than before treatment, mean 11.8 (3) $\mathrm{mmol} / \mathrm{l}(\mathrm{p}<0.02)$. The long term metabolic control, however, remained stable as indicated by haemoglobin $A_{1 c}$ (mean

\section{Discussion}

Our short term study was conducted to see if the glomerular filtration rate is dependent on angiotensin II concentrations in diabetic nephropathy. Our results show that this is not the case in mild hypertensive insulin-dependent diabetics with early nephropathy (glomerular filtration rate $>70 \mathrm{ml} / \mathrm{min} / 1 \cdot 73 \mathrm{~m}^{2}$ ), as angiotensin converting enzyme inhibition for one week did not affect glomerular filtration rate despite a mean reduction in blood pressure of $8 \mathrm{~mm}$ $\mathrm{Hg}$. Our finding of a significant decrease in albuminuria may be explained by diminished glomerular capillary hydraulic pressure induced by the angiotensin converting enzyme inhibition. ${ }^{2122}$ Consequently, a diminished glomerular filtration rate would be expected, unless some of the remaining determinants of glomerular filtration rate - that is, renal plasma flow and glomerular ultrafiltration coefficient, are changed in the opposite direction. Enhanced renal plasma flow has been shown during angiotensin converting enzyme inhibition in essential hypertension, despite the reduction in blood pressure. ${ }^{234}$ Intravenous infusion of a suppressor dose of angiotensin II in the rat causes profound changes in all three major determinants of filtration rate-increased glomerular capillary hydraulic pressure, diminished glomerular plasma flow, and reduced glomerular ultrafiltration coefficient - resulting in a slight reduction in glomerular filtration rate. ${ }^{25} 26$ Angiotensin converting enzyme inhibition in this animal model has the opposite effects. ${ }^{26}$

Mean arterial blood pressure fell from 112 to $102 \mathrm{~mm} \mathrm{Hg}$ during the 12 weeks of captopril treatment. Three out of 16 patients had no reduction in blood pressure. We might have expected an even greater failure rate as our study showed that the renin-angiotensinaldosterone system is already suppressed in untreated insulin dependent diabetics with early nephropathy. It is well established that this system is suppressed in advanced diabetic nephropathy, probably owing to retention of sodium and fluid. ${ }^{27}$ We have suggested the use of the molar ratio between the plasma concentrations of angiotensin I (the precursor decapeptide) and angiotensin II (the effector octapeptide) as a logical index of angiotensin converting enzyme inhibition. ${ }^{28}$ As shown in table III, this index documents effective angiotensin converting enzyme inhibition in our patients treated with captopril. Angiotensin II plasma concentrations do 
not, however, decrease significantly from the initial, quite low values; this is not very surprising in view of the known blank value, caused by immunoreactive peptides other than true angiotensin II octapeptide. ${ }^{29}$ The plasma concentration of aldosterone was low and remained unchanged in our study and extracellular fluid volume diminished. This volume depletion may well contribute to the observed hypotensive effect of captopril. It should be emphasised that sodium intake was unchanged and restriction not applied in our study. Urinary sodium excretion showed no significant changes.

Monotherapy with low dose captopril for 12 weeks induced changes in glomerular filtration rate of the same order of magnitude as previously shown for other antihypertensive drugs. ${ }^{10}$ This suggests an effect of blood pressure reduction per se on glomerular filtration rate. Four out of 16 patients had a drop in glomerular filtration rate of more than $10 \%$ of the pretreatment values. Impaired autoregulation of glomerular filtration rate is probably the major causative factor. ${ }^{30}$ Despite the reduction in glomerular filtration rate at the start of effective antihypertensive treatment, long term observations clearly indicate that careful blood pressure control slows the progression of diabetic nephropathy..$^{1031}$

Our finding of diminished albuminuria (32\%) can be explained neither by the slight decrease in glomerular filtration rate $(6 \%)$ nor by improved metabolic control. ${ }^{32}{ }^{33}$ Lowering of glomerular capillary hydraulic pressure may, as recently suggested, be the crucial factor. ${ }^{34}$ Micropuncture studies in hypertensive and diabetic rats have shown that angiotensin converting enzyme inhibition reduces the intraglomerular hypertension and albuminuria. ${ }^{21} 22$ The reduction in glomerular hypertension during angiotensin converting enzyme inhibition is a result of lower systemic arterial blood pressure and of a diminished efferent arteriolar resistance. Moreover, arterial hypertension induces an appreciable rise in glomerular capillary hydraulic pressure in streptozotocin diabetic spontaneous hypertensive rats $\left(52.6\right.$ versus $43.8 \mathrm{~mm} \mathrm{Hg}$ in non-diabetic rats). ${ }^{3 .}$ This finding provides a possible explanation for the damaging effect of hypertension in diabetes and for the beneficial effect of aggressive antihypertensive treatment on kidney function in established diabetic nephropathy. ${ }^{1021}$

Angiotensin converting enzyme inhibitors have been regarded as rather toxic drugs. This misleading picture of toxicity has emerged because in early studies too high a dose of captopril was used and without adequate dose reduction in renal failure. ${ }^{36}$ Subsequently, it was shown that even in patients with normal kidney function many of the side effects of captopril were dose related and could be avoided by using less than $150 \mathrm{mg}$ daily with little or no loss of efficacy. ${ }^{37}$ i8 Most commonly used antihypertensive drugs-for example, $\beta$ blockers and diuretics-reduce glucose tolerance in normal and diabetic people. ${ }^{39}$ t0 Furthermore, $\beta$ blockers can mask some clinical signs of hypoglycaemia and prolong the blood glucose recovery after a hypoglycaemic attack. These problems are not present during angiotensin converting enzyme inhibition, which may actually enhance insulin sensitivity. ${ }^{37+}$

In conclusion, the results of our study show that glomerular filtration rate is not dependent on angiotensin II concentrations in diabetic nephropathy, that albuminuria is pressure dependent to a large extent, and that captopril represents a valuable new drug for treating hypertensive type I diabetic patients with nephropathy.

\section{References}

1 Hricik DE, Browning PJ, Koppelman R, Goorno WE, Madias NE, Dzau VJ. Captopril-induced functional renal insufficiency in patients with bilateral renal-artery stenosis or renal-artery functional renal insufficiency in patients with bilateral re
stenosis in a solitary kidney. $N$ Engl Med 1983;308:373-6.

2 Curtis JJ, Luke RG, Whetchel JD, Diethelm AD, Jones P, Dustan HP. Inhibition of angiotensinconverting enzyme in renal-transplant recipients with hypertension. $N$ Engl $\mathcal{J}$ Med 1983;308: $377-81$

3 Blythe WB. Captopril and renal autoregulation. N Engl F Med 1983;308:390-1.

4 Davin JC, Mahieu PR. Captopril-associated renal failure with endarteritis but not renal-arter stenosis in transplant recipient. Lancet 1985; ;:820.

5 Brivel F, Roulot D, Paitrine A, Dormont J. Reversible acute renal failure during enalapril treatment in patients with chronic glomerulonephritis without renal artery stenosis. Lance $1985 ;$; : 1512

6 Mogensen CE. Progression of nephropathy in long-term diabetics with proteinuria and effect of initial anti-hypertensive treatment. Scand f Clin Lab Invest 1976;36:383-8.

7 Bohrer MP, Deen WM, Robertson CR, Brenner BM. Mechanism of angiotensin II-induced proteinuria in the rat. Am $\mathcal{F}$ Physiol 1977;233:F13-21.
8 Hostetter TH, Rennke HG, Brenner BM. The case for intrarenal hypertension in the initiation and progression of diabetic and other glomerulopathies. Am f Med 1982;72:373-80.

9 Parving $\mathrm{H}-\mathrm{H}$, Viberti GC, Keen H, Christiansen JS, Lassen NA. Hemodynamic factors in the genesis of diabetic microangiopathy. Metabolism 1983;32:943-9.

10 Parving H-H, Andersen AR, Smidt UM, Svendsen PAa. Early aggressive antihypertensive treatment reduces rate of decline in kidney function in diabetic nephropathy. Lance $1983 ; \mathrm{i}: 1175-9$.

11 Bröchner-Mortensen J, Giese J, Rossing N. Renal inulin clearance versus total plasma clearance of ${ }^{51}$ Cr-EDTA. Scand $\mathcal{F}$ Clin Lab Invest 1969;23:301-5.

12 Ladegaard-Pedersen HJ. Measurement of extra-cellular volume and renal clearance by a sing injection of inulin. Scand f Clin Lab Invest 1972;29:145-53.

13 Miles DW, Mogensen CE, Gundersen HJG. Radioimmunoassay for urinary albumin using single antibody. Scand $\mathcal{F}$ Clin Lab Invest 1970;26:5-11.

14 Schiøler V, Damkjær Nielsen M, Kappelgaard AM, Giese J. Partial purification of human renin substrate. Eur 7 Clin Invest 1976;6:229-40.

15 Giese J, Damkjær Nielsen M, Kappelgaard AM. Concentrations of active and inactive renin in human plasma: concepts and methodology. In: Sambhi MP, ed. Heterogeneity of renin and reninsubstrate. Holland: Elsevier North, 1981: 205-13.

16 Rasmussen S, Damkjær Nielsen M, Giese J. Captopril combined with thiazide lowers reni substrate concentration: implications for methodology in renin assays. Clin Sci 1981;60:590-3.

17 Kappelgaard AM, Damkjær Nielsen M, Giese J. Measurement of angiotensin II in human plasm technical modifications and practical experience. Clin Chim Acta 1976;67:299-306.

18 Bruun NE, Ibsen H, Nielsen F, Nielsen MD, Moelbak A-G, Hartling OJ. Lack of activation of counter-regulatory mechanisms to long-term nifedipine treatment in essential hypertension. Hypertension (in press)

9 Laurell C-B. Quantitative estimation of proteins by electrophoresis in agarose gel containin antibodies. Anal Biochem 1966;15:45-52.

20 Mortensen $\mathrm{HB}$. Quantitative determination of hemoglobin $\mathrm{A}_{\mathrm{lc}}$ by thinlayer isoelectric focusing. f Chromatogr 1980;182:325-33.

21 Meyer TW, Anderson S, Rennke HG, Brenner BM. Control of glomerular hypertension retards progression of established glomerular injury in rats with renal ablation [Abstract]. Kidney In 1985;27:247.

22 Zatz R, Meyer TW, Dunn BR, et al. Lowering of arterial pressure (MAP) limits glomerula hypertension and albuminuria in experimental diabetes [Abstract]. Kidney Int 1985;27:252.

23 Hollenberg NK, Meggs LG, Williams GH, Katz J, Garnic JD, Harrington DP. Sodium intake and renal responses to captopril in normal man and in essential hypertension. Kidney Int $1981 ; 20: 240-5$.

24 Simon G, Morioka S, Snyder DK, Cohn JN. Increased renal plasma flow in long-term enalapril treatment of hypertension. Clin Pharmacol Ther 1983;34:459-65.

25 Myers BD, Deen WM, Brenner BM. Effects of norepinephrine and angiotensin II on the determinants of glomerular ultrafiltration and proximal tubule fluid reabsorption in the rat. Cir Res 1975;37:101-10

26 Ichikawa J, Brenner BM. Glomerular actions of angiotensin II. Am F Med 1984;76:43-9.

27 Christlieb AR, Kaldany A, D'Elia JA, Williams GH. Aldosterone responsiveness in patients with diabetes mellitus. Diabetes 1978;27:732-7.

28 Giese J, Rasmussen S, Nielsen MD, Ibsen $\mathrm{H}$. Biochemical monitoring of vasoactive peptide during angiotensin converting enzyme inhibition. Hypertension 1983; 1(suppl 1):31-6.

29 Nussberger J, Brenner DB, Waeber B, Brenner HR. True versus immunoreactive angiotensin in human plasma. Hypertension 1985; 7 (suppl 1):1-7.

30 Parving H-H, Kastrup H, Smidt UM, Andersen AR, Feldt-Rasmussen B, Sandahl Christiansen J. Impaired autoregulation of glomerular filtration rate in type 1 (insulin-dependent) diabetic Impaired autoregulation of glomerular filtration rate in

31 Mogensen CE. Long-term antihypertensive treatment inhibiting progression of diabetic nephropathy. BrMed $\mathcal{F}$ 1982;285:685-8.

32 Viberti GC, Bilous RW, Mackintosh D, Bending JJ, Keen HC. Long-term corrections of hyperglycaemia and progression of renal failure in insulin-dependent diabetes. $\mathrm{Br} \mathrm{Med}$ 1983;286:598-601.

33 Christiansen JS, Parving H-H. The effect of short-term strict metabolic control on albuminuria in insulin-dependent diabetics with normal kidney function and diabetic nephropathy. Diabetic Nephropathy 1984;3:127-9.

34 Taguma Y, Kitamoto Y, Futaki G, Ueda H, Monma H, Ishizaki M, Takahashi H, Sekino H Sasaki Y. Effect of captopril on heavy proteinuria in azotemic diabetics. $N$ Engl $\mathcal{F} M e d$ 1985;313:1617-20

35 Bank N, Klose R, Aynedjin HS. Glomerular pressure in rats with diabetes and hypertension [Abstract]. Kidney Int 1985;27:241.

36 Heel RC, Brogden RN, Speight TN, Avery GS. Captopril: a preliminary review of its pharmacological properties and therapeutic efficacy. Drugs 1980;20:409-52.

37 Edwards CRS, Padfield PL. Angiotensin-converting enzyme inhibitors: past, present and bright future. Lancet $1985 ; \mathrm{i}: 30-4$

38 Veterans Administration Cooperative Study Group on Antihypertensive Agents. Low-dose captopril for the treatment of mild to moderate hypertension. Arch Intern Med 1984;144: 1947-53.

39 Struthers AD. The choice of antihypertensive therapy in the diabetic patient. Postgrad Med 1985;61:563-9.

40 Bengtsson C, Blohme G, Lapidus L, et al. Do antihypertensive drugs precipitate diabetes? Br.Med f 1984;289:1495-7.

41 Ferriere M, Lackkar H, Richard J-L, Bringer J, Orsetti A, Mirouze J. Captopril and insulin sensitivity. Ann Intern Med 1985;102:134-5.

(Accepted 27 May 1986)

\section{YEARS AGO}

The intense heat which has prevailed here during several days this week has been felt with increased force in Paris, where, we are informed, a large number of cases of sunstroke have occurred among the recruits taking part in the autumn manoeuvres, and four deaths are said to have taken place. In the north of France, where the thermometer has stood in the shade at $104^{\circ}$ Fahr., the troops have suffered very severely. From the official returns, it appears that on Wednesday, at Lille, six soldiers of the regular army had died from sunstroke, and that twenty-three, suffering from the same cause, were in the military hospital. Instructions have been issued to the commandant of army corps to suspend evolutions during the great heat of the day. (British Medical fournal 1886;ii:466.) 